\title{
Exploit the Ocean for Extra Housing Supply: A Comparison between the Floating House and Houseboat
}

\section{Review Article}

Volume 2 Issue 2- 2021

\author{
Author Details \\ Xinhao Wang and Shi-Yu Xu* \\ Department of Architecture and Civil Engineering, City University of Hong Kong, Hong Kong \\ *Corresponding author
}

Shi-Yu XU, Department of Architecture and Civil Engineering, City University of Hong Kong, Hong Kong

Article History

Received: April 28, 2021 Accepted: May 11, 2021 Published: May 12, 2021

\begin{abstract}
The rapid development of coastal areas often leads to housing shortage, subsequently resulting in poor living quality and unaffordable home prices. People thus start to set their sights on the sea. The floating house and houseboat are unique alternative solutions to the said housing crisis in major coastal cities. This article reviews and compares the characteristics of the floating house and houseboat and recommended a few directions for preliminary works that should be completed before launching these kinds of housing projects in coastal waters.
\end{abstract}

\section{Introduction}

The coastal regions have long been the favored terrain for human colonization due to the proximity to ocean resources, flat coastal plains, and convenient marine transportation, etc. The dense human population grants rapid development in these areas, ultimately leading to intense land use and expensive land price [1]. Residents in the coastal cities thus often suffer from the overcrowded urban atmosphere, limited living space, soaring housing price, and so forth. In addition, the global warming and subsequent sea level rise is posing greater threats to the low-elevation coastal areas than ever [2]. Many coastal cities and island countries now battle with more severe and frequent floods resulting from the rising water level in conjunction with the extreme weather events, for example, at Venice, Miami, and Tuvalu [3-5]. Land reclamation is one choice to provide additional land supply, which, however, will inevitably harm the environment at the same time [6]. Facing this predicament, people start to turn eyes to a unique potential solution - the floating house and houseboat.

The modern floating house originates from the traditional houseboat; the latter has long been adopted as an affordable solution for poor or displaced people in many countries and areas [7,8]. While some houseboats still serve as long-term accommodations, others have been reshaped into recreational places for experiencing special living or entertainment styles on water, such as vacation villages and fishing sites. In contrast, the floating house is more thoroughly developed in its living functions. Figure 1 shows the examples of modern floating houses and houseboats in Netherlands and America, respectively.

The floating house differs from the houseboat primarily in the three aspects listed below. These differences determine the roles that the floating house and houseboat can play in overall urban planning and local community development:

(1) Modern floating houses are designed for high quality living and follow highly regulated planning, with self-propulsion capability abandoned. On the contrary, most houseboats are motorized, especially those used for vacation rentals [11]. This is also the reason why floating houses can be financially classified as immovable properties [12].

(2) The floating house is tailored to permanent abode; therefore, some of its components are remodeled to increase its accommodation capacity. Floating house often has a low-rise superstructure (usually with two stories) made of light-weight materials, standing on a stable floating platform as its foundation. Comparatively, the houseboat still keeps the seaworthy hull, with the cabin modified for residential use in one single level.

(3) Navigable houseboats are not intended to be kept stationary at fixed locations; hence, they are moored using dock lines only temporarily when necessary [13]. The floating houses, on the other hand, are designed to remain connected to the land to ensure convenient access to the utilities (e.g., tap water, sewer, and power). 


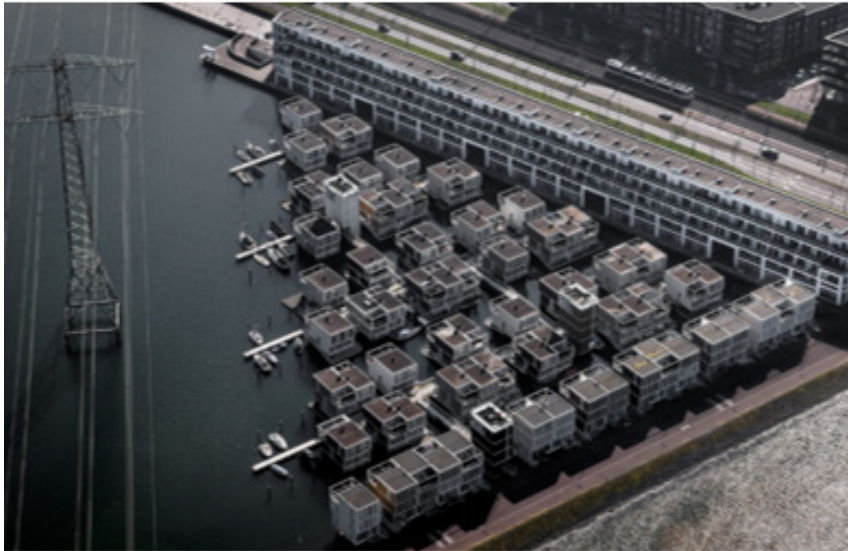

Figure 1: (a) Floating houses in IJburg, Amsterdam, Netherlands [9].

\section{Before Large-Scale Deployment in Coastal Waters}

As mentioned above, though sharing the same origin, the floating house and houseboat actually possess a few distinct key features, and thus have their own strengths and weaknesses. In many aspects, the floating house is just like the land-based house; it comes with stable substructure and mooring system, convenient utilities, large floor area, and so on. Comparatively, the houseboat is basically a refit boat which cannot provide such high quality living, although it costs less as compared to the floating house. The major strength of the houseboat lies in its mobility, allowing it to easily change location by its own. This characteristic makes the houseboat particularly suitable for tourism purpose, as the owners/leaseholders can have the freedom to enjoy diverse waterfront sceneries in different water areas and sail to safe areas before the extreme wind or wave events attack. Contrastively, the limited mobility is a weakness of the floating house as it has to be towed to place with a tugboat and usually no longer moves once settled. This weakness, however, is not really a drawback for the longterm dwelling purpose, considering that the residents need stable and reliable connection to the land for routine activities (e.g., daily work/ education, grocery shopping, etc.) and utility services. Regardless of the self-propulsion ability, living over the sea will involve many new challenges that have rarely been investigated before. Below are a few directions for preliminary studies we recommend the housing and building departments of the governments of major coastal cities to consider before adopting the floating house and houseboat as a potential housing policy.

a. The performance of the floating house/houseboat (in terms of structural stability and the comfort issue, etc.) depends largely on the sea state. The optimal sites are those where the surrounding waters are relatively calm. It is therefore vital to monitor the longterm wave and wind conditions and collect local hydrographic information at the potential sites on a regular basis in search for the optimal site.

b. Being a new type of housing product, the public acceptance and financial feasibility must be examined before launching it in the local residential market. As the construction costs of the house and required supporting facilities (including the land price, material and labor costs, and consulting fees for professional services) vary from one market to another, customized costperformance analysis comparing the floating houses with the land-based houses should be carried out to determine whether it is worthy of investment [14].

c. Living on water, the comfort, health, safety, and structural related issues are particularly important, especially when exposure to the extreme wind or wave is expected. Local standards concerning the design details, material selection, and dynamic performance, etc. of the floating house/houseboat should be established based on

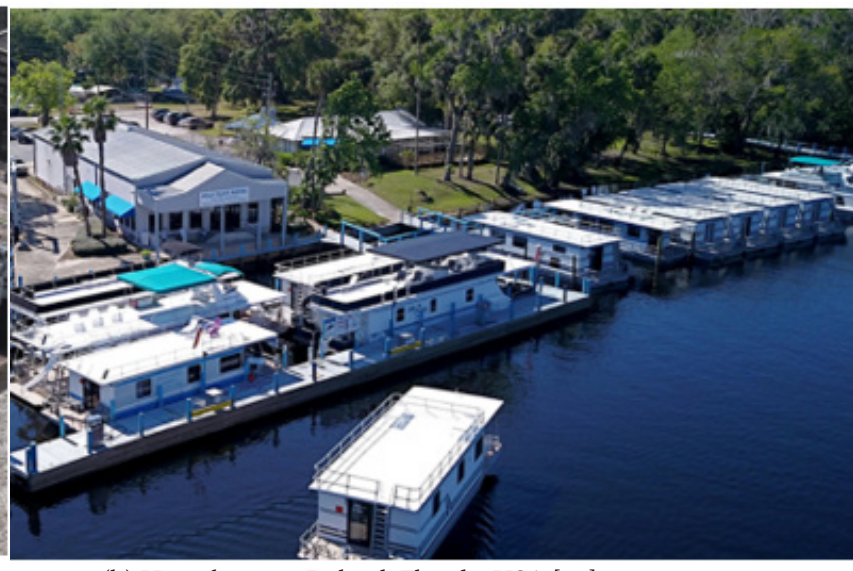

(b) Houseboats in Deland, Florida, USA [10].

the dynamic responses of the floating house/houseboat, obtained through either physical tests or advanced numerical simulations, when subject to realistic wind and wave conditions.

d. Some technical difficulties of living on water including the humidity problem, wave reduction, structural damping, maintenance, and so forth, should be thoroughly investigated to ensure an acceptable living quality as on land.

e. As the floating houses have higher requirements on community planning and supporting facilities, before launching a large-scale project, deployment of a few small-scale pilot projects (such as the holiday rental floating houses for visitors) are recommended in order to test local citizen's acceptance of the new housing product and gain practical experiences in evaluating whether all the technical problems are resolved.

f. Remodeling the old freight ships for temporary dwelling may be seen as a quicker alternative solution, as these kinds of ships are much larger, more stable, and can accommodate more residents than the traditional houseboats. Nonetheless, as the freight ship is not tailormade for long-term living, its living quarters, especially those located below the ship deck, may not meet the lighting, ventilation, and fire safety standards of an acceptable dwelling. Hence, extensive research and evaluations regarding the longterm impacts on the residents' health conditions and mental status may be required.

g. Conventional building regulations usually govern the design and construction of building facilities built on land only and may not be applicable to the housing projects deployed over the sea. Furthermore, launching a large-scale floating house project may stimulate the disputes over the ownership of the water area or incite waterfront conflicts among neighboring house owners, fishermen, aquaculture industry, etc. [15]. Therefore, legal aspects including the associated laws or policies for construction, placement, residency, taxation, and so forth, of the floating houses/houseboats must be well prepared in advance.

\section{Summary}

The floating house and houseboat develop the sea surface for residential use, relieving the living problems in overcrowded coastal cities. In this article, the major differences of the two housing products are reviewed, with strengths and weaknesses briefly discussed. A series of future work directions have been summarized, concerning various practical problems such as site selection, financial feasibility, dynamic performance, technical challenges, legal aspects, and physical/mental health issues. Before mass production, deploying some small-scale pilot projects (e.g., holiday rental floating houses and/or vacation rental houseboat) to test local citizen's acceptance are highly recommended. 


\section{References}

1. Creel L (2003) Ripple effects: population and coastal regions. Washington DC, USA: Population Reference Bureau; p. 1-7.

2. Church JA, PU Clark, A Cazenave, JM Gregory, S Jevrejeva, et al. Sea Level Change. In: Stocker T F, D Qin, et al. (eds). Climate Change 2013 The Physical Science Basis. Contribution of Working Group I to the Fifth Assessment Report of the Intergovernmental Panel on Climate Change. Cambridge University Press: USA; 2013.

3. https://www.nbcnews.com/news/world/sea-levels-rise-venice-fightsstay-above-waterline-n1135661.

4. https://www.businessinsider.com/miami-floods-sea-level-risesolutions-2018-4

5. https://www.pacificclimatechange.net/document/tuvalu-nationaladaptation-programme-action-napa-official-document.

6. OSPAR. Assessment of the environmental impact of land reclamation. London, UK: OSPAR Commission; 2008.

7. Modes W. The secret history of American river people: an anthro- historical research journey through the history of a river. UC, Santa Cruz: Division of Graduate Studies; 2014.

8. Team Hong Kong Living. 2021 The history of Aberdeen's floating villages.

9. Mcnulty Kowal S (2020) These floating homes in Amsterdam are designed to beat the rising sea levels and escape the growing city population.

10. Holly Bluff Marina (2021) Houseboat amenities.

11. Peter Kimberly (2020) Houseboat Driving Lessons : learn how to park, dock, and drive houseboats.

12. Arch Daily (2011) Floating houses in IJburg/Architectenbureau Marlies Rohmer.

13. Denver Rope (2017) Houseboat lines.

14. SAVE. Monograph - function: definition and analysis. Mount Royal, New Jersey: SAVE International; 1998.

15. Middle Peninsula Planning District Commission (2010) A planning report: law and policy regarding floating homes. 